\title{
Climate change adaptation narratives: Linking climate knowledge and future thinking
}

\author{
Liese Coulter $^{\mathrm{a}, *}$, Silvia Serrao-Neumann ${ }^{\text {a, b }}$, Eddo Coiacetto $^{\text {a }}$ \\ a Cities Research Institute, Griffith University, 170 Kessels Rd, Nathan, Brisbane 4111, Australia \\ ${ }^{\mathrm{b}}$ School of Social Sciences, The University of Waikato, Private Bag 3105, Hamilton 3240, New Zealand
}

\section{A R T I C L E INFO}

\section{Keywords:}

Autonomous

Change

Communication

Decision-maker

Distance

Prospection

\begin{abstract}
A B S T R A C T
Even in countries with high capacity to adapt to climate change, when future-oriented adaptation narratives are neither explicit nor common, climate knowledge may not be accessed, examined, or shared to support active adaptation. This research analyzed interviews with Australian and Canadian professionals who worked with climate change knowledge in research, policy, and practice to gauge in what way their climate knowledge was linked to autonomous adaptation in personal circles. Analysis combined a thematic approach and a novel Future Climate Narrative (FCN) typology informed by literature relating to Future Thinking, Climate Knowledge and Narrative Communication. The results identified four main narratives: Distance, Vulnerability, Agency, and Change. Findings showed that where Change narratives were not commonly shared, little climate change knowledge was exchanged in personal circles, especially information that might increase a sense of danger; challenge the imagination; or present unfamiliar scenarios. This research shows that without future-oriented narratives supporting autonomous and community adaptation planning and practice, the benefits of currently high social adaptive capacity and relatively low vulnerability to climate change may not be realized through proactive adaptation. In developed nations where near- term, and in some cases unavoidable, climate change impacts are not commonly discussed, new Change narratives linking Climate Knowledge and Future Thinking are needed to reflect swiftly evolving climate change scenarios. In addition, lack of adaptation planning among well-informed professionals again challenges expectations that more and better climate change knowledge will directly increase adaptation behaviour, irrespective of engagement in future thinking.
\end{abstract}

\section{Introduction}

Climate change adaptation aims to reduce or manage impacts and risks from climate change, that, in the near term, are likely first experienced through severe weather events (Kirtman et al., 2013). Preparation for, response to, and recovery from these events are usually managed by national and regional governing bodies, assisted by international organizations such as the United Nations (UN) and International Federation of Red Cross and Red Crescent Societies (IFRC), which provide valuable climate data and context for decision-makers. Hence, official, government-led adaptation is often based on technical and complex interactions, frequently framed as climate risks in the context of International Panel on Climate Change (IPCC) reports on global environmental change (Field et al., 2014). Application of the best available climate change knowledge depends on high level engagement between climate

\footnotetext{
* Corresponding author.

Email address: liese.coulter@gmail.com (L. Coulter)
} 
service providers and users (Hewitt, Stone, \& Tait, 2017). While data application is vital to manage these large-scale endeavors, they are difficult to interpret and apply in local contexts (Bai et al., 2016; Hurlbert \& Gupta, 2016) making climate information only valuable on smaller scales when it supports locally-based actions (Coughlan de Perez et al., 2015).

When viewed from such a global scale, individual and autonomous adaptations are often discussed as relatively insignificant and likely ineffective (Preston, Mustelin, \& Maloney, 2015), largely because they are seen as reactive and uncoordinated efforts (Moser, 2014). Nevertheless, there is a growing call for more community-based adaptation to address unavoidable climate impacts (McNamara \& Buggy, 2016). While the number of studies researching adaptation drivers and barriers has been growing over the past five years, especially stemming from the model of protection motivation put forth by Grothmann and Patt (2005)), engagement in autonomous climate change adaptation is little researched (Hinkel \& Bisaro, 2015).

Autonomous adaptation is carried out by non-government stakeholders with some access to climate change knowledge (Klein \& Juhola, 2014). Where place attachment and identity is fundamental, such as in Indigenous communities, climate change knowledge is framed by experience and personal observation, or underpinned by tacit knowledge (Petrasek MacDonald et al., 2013). This contrasts with the abstract scientific knowledge informing public policy. Therefore, it is useful to understand the climate context for these professional actors, who themselves frame climate narratives within their personal, cultural and employment communities (Fløttum \& Gjerstad, 2017).

Additionally, an important factor in understanding changes in climate patterns is the quality of stationarity, which refers to the climate system as highly variable but operating within the boundaries of a relatively unchanging envelope of extremes (Milly et al., 2008). A defining characteristic of anthropogenic climate change is that the climate system no longer operates within stationary boundaries (Craig, 2010). The new limits of ongoing and unprecedented environmental extremes are challenging to incorporate into personal and social visions of the future (Smith et al., 2011). Continual change requires persistent engagement in thinking about the future, to assess the implications of emergent climate impacts and consequent responses (Bai et al., 2016; Grothmann \& Patt, 2005).

In this way, this paper argues that Climate Knowledge informs, and is informed by, Future Thinking through Narrative Communication; thus shaping the ways climate change is understood, imagined, and communicated (Fig. 1).

Common climate narratives are founded on the global climate system of the past and contextualized through UN climate change themes of environmental sustainability and international development (Blaxekjær \& Nielsen, 2014). In contrast, emerging transformative narratives use knowledge of global environmental change for future-focused portrayals of a new Anthropocene era that will continually require significant adjustments and adaptations (Brondizio et al., 2016; Steffen et al., 2018). Narratives of sustainability and development usefully focus on mitigating causes of climate change by sharing responsibility and resources (Moser, 2014) however, they offer little communication and heuristic benefit to adapt to unavoidable consequences of global environmental change (Preston et al., 2015).

While much adaptation research has focused on developing and communicating climate information, the roles of Future Thinking and collective future thought (Szpunar \& Szpunar, 2016) are not well represented or considered (Sardar, 2015). The ability to anticipate and plan for uncertain events and contingencies has contributed to the survival of the human species (Suddendorf, 2017). However, climate narratives rarely frame the consequences of climate change in terms of Future Thinking, a process that can explicitly take account of ongoing climate change impacts to reimagine what might happen in the future (Szpunar, Spreng, \& Schacter, 2014; Merck, Topcu, \& Hirst, 2016). Instead, future representations tend to depend on predictive trends and expert scenarios that have little room for the complexity of bottom-up or autonomous adaptation (Gidley et al., 2009; Serrao-Neumann et al., 2013).

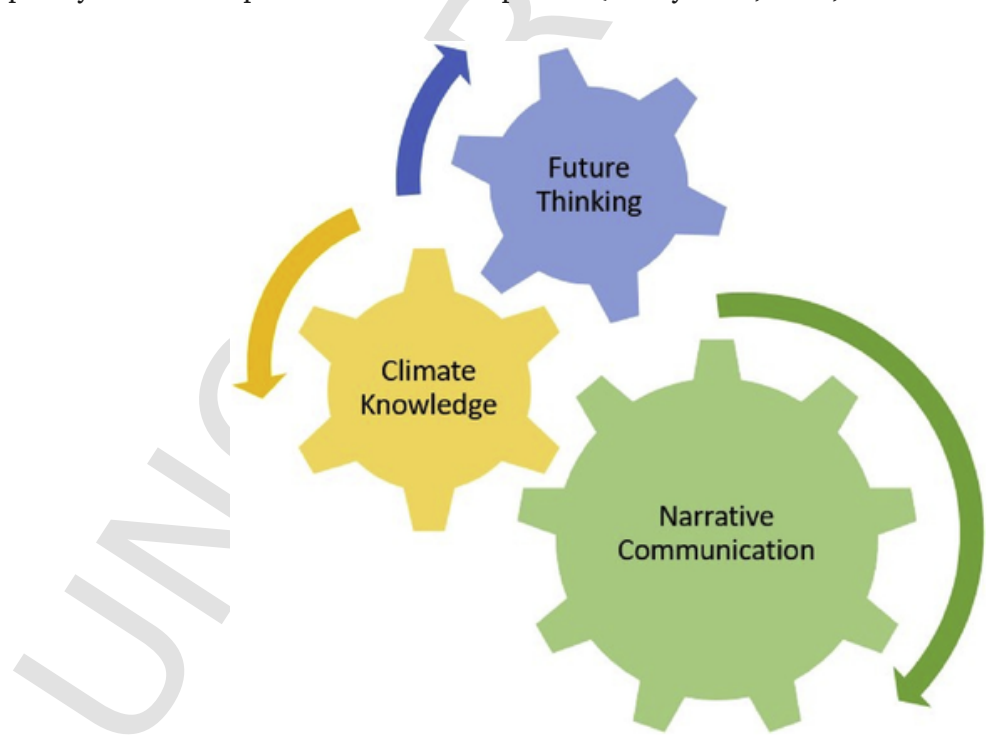

Fig. 1. Schematic relationship of Future Thinking, Climate Knowledge and Narrative Communication for decision making. 
In parallel, cognitive science offers insights into the relationship between Narrative Communication and Future Thinking. Unfortunately, even professionals who work with climate information face time constraints and social norms that inhibit or prevent developing narratives situating climate change as personally relevant (Hewitt et al., 2017; Jones, Hine, \& Marks, 2017). Without conversations that share memories and imaginings based on relevant experiences and knowledge, climate information is not reflected in risk assessments and forward planning (Miller et al., 2015); through either episodic thinking informed by personal experience, or semantic thinking that draws on knowledge of society (Suddendorf \& Corballis, 2007).

Future Thinking is a type of future-oriented cognition, or prospection. According to a useful taxonomy of prospection, both personal and social planning can be simply considered in four modes: simulation; prediction; intention; and planning (Szpunar et al., 2014). A short-term example of these could involve; first, mentally simulating being affected by an expected heat wave; second, predicting that air conditioning would reduce heat stress; then, intending to spend the day in an air-conditioned building; and finally, planning how to get to the building.

For longer-term adaptation planning, knowledge of a non-stationary climate system would particularly need to inform the stages of simulation and prediction. Otherwise, uncertain and ongoing change for oneself and society will not be incorporated in future visions. In that case, if the stages of intention and planning are based on assumptions of a stationary climate system, there is little opportunity in further plans to correct those assumptions, without continual reassessment.

Professionals who work with climate change knowledge in research, policy and practice should be well placed to engage in autonomous adaptation, as access to such information can enable climate change adaptation (Hewitt et al., 2017; Oakes, Ardoin, \& Lambin, 2016). However, without a shared and personally relevant adaptation narrative, there is little motivation to adapt, as projected climate change risks are often assigned to future generations and distant countries (Jones et al., 2017; Spence, Poortinga, \& Pidgeon, 2012). It is important to understand how climate risks are seen and shared from the perspective of those who might adapt, especially in terms of their own sense of vulnerability and agency (Smith et al., 2011).

This research addresses what narratives climate professionals have developed to communicate and apply their knowledge of climate change in personal circles, especially to support adaptation over the next twenty years. Through applying a Future Climate Narrative typology underpinned by intersecting factors of Future Thinking, Climate Knowledge and Narrative Communication, the paper explores the extent to which climate professionals use prospection in autonomous adaptation planning. While the importance of communicating climate information is increasingly recognized in public communication (Moser, 2016) and in the emerging field of climate services (Harjanne, 2017), the role of Future Thinking in understanding and applying Climate Knowledge is little researched or theorized (Suddendorf \& Corballis, 2007; Szpunar \& Szpunar, 2016; Tonn \& MacGregor, 2009). Therefore, the typology is especially suitable to examine the role of thinking about the future, or prospection, within climate professional's narratives.

The following section presents the research approach employing the Future Climate Narrative typology and thematic analysis. Then, the resulting narratives of Distance, Vulnerability, Agency and Change are described, and subsequently discussed, to consider how different narratives influence decisions to undertake autonomous adaptation. The paper concludes with the implications of low engagement in Climate change Adaptation Narratives and the need to explicitly understand the role of prospection in how climate change adaptation is imagined, discussed and carried out to better inform both the communication and application of climate change knowledge for autonomous adaptation.

\section{Research approach and methods}

This paper takes a qualitative research approach to investigate what future-oriented climate narratives are being constructed and shared by those developing, applying or communicating climate change knowledge in Canada and Australia. Both countries were chosen for the case study based on similarities in their high per capita greenhouse gas emissions, natural resource-based economies and approaches to federal government (Jones, 2012) as well as dissimilarities in their climates.

Data were collected through 31 semi-structured interviews carried out between June 2014 and April 2015. Interviewees were purposefully selected (Huberman \& Miles, 2002) based on their work in developing, applying or communicating climate information; were publicly linked to related professional roles, reports or presentations; and, drawn from five Canadian provinces and six Australian states and territories, to minimize regional bias. Hence, interviewees were evenly distributed among three work roles: researchers, policy-makers and practitioners. Interviewees were identified by an alphanumeric code indicating professional role (RE: Researcher; PO: Policy-maker; PR: Practitioner) and either A: Australian or C: Canadian (see Table 1). Recruitment, interviews and data management adhered to an approved ethics protocol and all data were de-identified to avoid conflict with personal or professional sensitivities.

The semi-structured interviews lasted one hour, were video recorded, with audio transcribed verbatim and video used only for clarification. In the interviews, participants were prompted to discuss how they talked with family and friends about adapting to climate change in the coming decades, following the IPCC definition of the near- erm, as the next twenty years (Kirtman et al., 2013).

Table 1

Interviewees' identification by country and role.

\begin{tabular}{llll}
\hline & Policy-maker ID & Practitioner ID & Researcher ID \\
\hline $\begin{array}{lll}\text { Australia } \\
\text { Canada }\end{array}$ & PO1A-PO5A & PR1A-PR5A & RE1A-RE5A \\
\hline
\end{tabular}


Interview content was categorized and summarized across both the deductive typology and inductive thematic analysis (Fereday \& Muir-Cochrane, 2006). This mainly content-driven approach (Braun \& Clarke, 2006) employed the Future Climate Narrative typology illustrated in Fig. 2, to structurally identify and organize key components within the data. Thereafter, thematic codes were derived from the data to reflect participant responses. Structural and thematic coding have been functionally combined to ensure rigor (Fereday \& Muir-Cochrane, 2006) in the research design and analysis.

The data were analyzed in four stages: first, structural and co-occurrence coding according to the Future Climate Narrative typology (see Section 2.1); second, data-driven coding and refinement which grouped responses into overarching themes; then, categorizing structural and data driven themes to identify dominant climate narratives; and finally, summarizing Climate Change Adaptation Narratives. The QSR computer software NVivo10 was used to code, sort and organize data for analysis (QSR International, 2012). See the supplementary information for an extended treatment of the research approach and methods.

\subsection{Applying the future climate narrative typology}

The Future Climate Narrative typology considers intersecting factors of Future Thinking, Climate Knowledge, and Narrative Communication. These intersections yielded four interplays between these factors in Climate Change Adaptation Narratives: Dangerous Futures; Imagined Futures; Unfamiliar Futures; and Adaptive Futures (see Fig. 2).

In the Future Climate Narrative typology, each type represents interactions between three key factors. The Dangerous Futures type intersects Climate Knowledge and Narrative Communication, which may not include Future Thinking to imagine the consequences of climate change. The label recognizes longstanding and frequently communicated messages that anthropogenic climate change is inherently dangerous and must be avoided (IPCC et al., 2014). Imagined Futures, intersecting Narrative Communication and Future Thinking, acknowledges the interplay between mental constructs and shared messages that shape how futures are envisioned for people, society, and the environment. However, this type may not include consideration of Climate Knowledge. Instead, current knowledge is incorporated into narratives, usually based on familiar experiences and memories (Yusoff \& Gabrys, 2011).

Unfamiliar Futures, at the intersection of Climate Knowledge and Future Thinking, acknowledges the unprecedented nature of a novel future affected by climate change. Nonetheless, these thoughts and imaginings may not be voiced, or explicitly communicated to others.

Finally, where all three factors are active, Adaptive Futures reflects the synergies associated with adapting to current and anticipated climate change impacts and their consequences, where the implications of climate change are understood as extending into the future; and where that future vision is communicated with others (Adger, Arnell, \& Tompkins, 2005). While adapting to climate change has already begun in some ecological and physical systems, the most significant social adaptation noted so far operates on personal and emotional levels, in coping with fear of what is to come (Hornsey et al., 2015). Key expressions identified by thematic analysis are shown for each type in Table 2.

In the semi-structured interviews, participants responded to prompts in their own ways, irrespective of the Future Climate Narrative typology. Accordingly, passages were initially coded by topic, then grouped into four overarching themes, namely: Personal, Social, or Environment (iteratively refined into 16 more specific sub-themes); and Temporal (according to references to time and transitions, comprising two sub-themes), shown in Tables 4-7.

Four Climate Change Adaptation Narratives were derived through thematic analysis, interpreted by applying the Future Climate Narrative typology: Distance, Vulnerability, Agency, and Change. The thematic inductive content analysis (Fereday \& Muir-

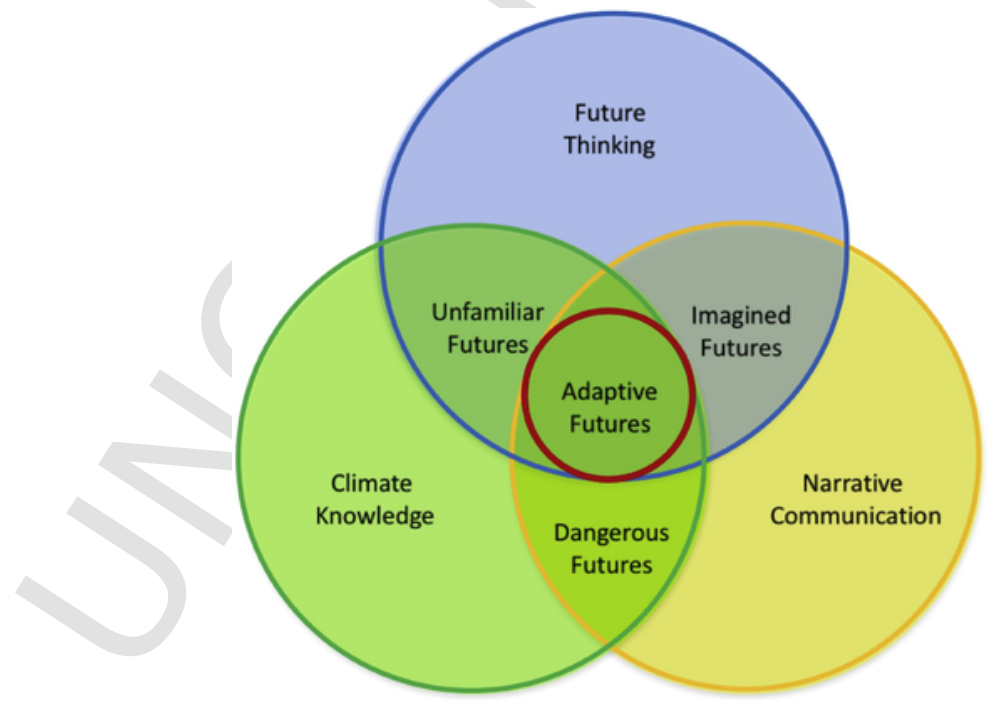

Fig. 2. Future Climate Narrative typology centered on the Adaptive Futures type shows intersections between Future Thinking, Climate Knowledge and Narrative Communication, and three other types: Dangerous Futures; Imagined Futures; and Unfamiliar Futures. 
Table 2

Key expressions by Future Climate Narrative type.

\begin{tabular}{|c|c|c|c|c|}
\hline FCN type & Dangerous Futures & Imagined Futures & Unfamiliar Futures & Adaptive Futures \\
\hline \multirow[t]{4}{*}{$\begin{array}{l}\text { Key } \\
\text { expressions }\end{array}$} & $\begin{array}{l}\text { minimizing scale and immediacy } \\
\text { of threat }\end{array}$ & $\begin{array}{l}\text { expecting others to be worse off } \\
\text { than self }\end{array}$ & feeling emotionally overwhelmed & $\begin{array}{l}\text { increasing personal } \\
\text { resilience }\end{array}$ \\
\hline & creating personal distance & $\begin{array}{l}\text { uncertain scale and time frame for } \\
\text { losses }\end{array}$ & $\begin{array}{l}\text { trying to imagine beyond } \\
\text { memories }\end{array}$ & $\begin{array}{l}\text { seeking like-minded } \\
\text { others }\end{array}$ \\
\hline & expressing fear & lacking basic necessities & $\begin{array}{l}\text { making personal observations of } \\
\text { change }\end{array}$ & $\begin{array}{l}\text { avoiding locked-in } \\
\text { choices }\end{array}$ \\
\hline & $\begin{array}{l}\text { avoiding discussions of climate } \\
\text { issues }\end{array}$ & $\begin{array}{l}\text { expecting failure of government to } \\
\text { manage }\end{array}$ & $\begin{array}{l}\text { expecting transformational } \\
\text { changes }\end{array}$ & $\begin{array}{l}\text { feeling cautiously } \\
\text { optimistic }\end{array}$ \\
\hline
\end{tabular}

Cochrane, 2006) indicated the dominance of participants' engagement with climate change and adaptation topics from Personal, Social or Environmental perspectives when prompted to discuss their conversations about near-term climate change adaptation. The Temporal theme uniquely applied to all topics and themes, framing discussions through specific events in time or relative references to another time in the past, present or future; thus making temporal references explicit when considering participants' perspectives on climate change.

In the Future Climate Narrative typology, the Unfamiliar Futures type rarely used Narrative Communication to connect inner thoughts and social conversations, which led to marked differences between personal and social expectations of the future. Therefore, when identifying Climate Change Adaptation Narratives, the Unfamiliar Futures type represented both Personal and Social perspectives. Table 3 shows Climate Change Adaptation Narratives by type and theme; with the understanding that knowledge was applied differently to estimate personal risks through episodic Future Thinking, and to estimate societal risks through semantic Future Thinking (Boomsma, Pahl, \& Andrade, 2016).

\section{Climate change adaptation narratives}

Participants engaged with various narratives throughout the interview, returning to comfortable or familiar topics unless prompted. Spontaneous comments generally focused on causes and mitigation of climate change, with rare mentions of the likely consequences, even when climate adaptation was a focus at work. References to a specific time signaled significant shifts and relative references to past and future were useful indicators for Future Thinking. Overall, responses grouped into four Climate Change Adaptation Narratives, set out in Table 4 with overviews of their Future Climate Narrative typological and thematic analyses (see Supplementary material for further details).

Table 3

Climate Change Adaptation Narratives of Distance; Vulnerability; Agency; and Adaptation by type and theme.

\begin{tabular}{l|l|l|l|l}
\hline \multicolumn{5}{c}{ Climate Change Adaptation Narratives } \\
\hline FCN TYPES & \multicolumn{1}{c}{ DISTANCE } & & \\
\hline $\begin{array}{l}\text { Dangerous } \\
\text { Futures }\end{array}$ & & & & \\
\hline $\begin{array}{l}\text { Imagined } \\
\text { Futures }\end{array}$ & & & & \\
\hline $\begin{array}{l}\text { Unfamiliar } \\
\text { Futures }\end{array}$ & & & & \\
\hline $\begin{array}{l}\text { Adaptive } \\
\text { Futures }\end{array}$ & & & & \\
\hline THEMES & & & & \\
\hline Personal & & & & \\
\hline Social & & & & \\
\hline Environment & & & & \\
\hline Temporal & & & & \\
\hline
\end{tabular}

\begin{tabular}{|l|l|l|l|}
$\begin{array}{l}\text { Engagement } \\
\text { legend }\end{array}$ & $\begin{array}{l}\text { Lightly } \\
\text { Engaged }\end{array}$ & $\begin{array}{l}\text { Moderately } \\
\text { Engaged }\end{array}$ & $\begin{array}{l}\text { Strongly } \\
\text { Engaged }\end{array}$ \\
\hline
\end{tabular}


Table 4

Climate Change Adaptation Narratives, descriptions and overview of Future Climate Narrative typological and thematic analyses.

\begin{tabular}{|c|c|c|}
\hline Narrative description & FCN analysis & Thematic analysis \\
\hline \multicolumn{3}{|l|}{ Distance } \\
\hline $\begin{array}{l}\text { Centered on the projected and } \\
\text { perceived distance of climate } \\
\text { threats, seen as dangerous but } \\
\text { mostly for distant others }\end{array}$ & $\begin{array}{l}\text { High engagement in Imagined Futures with little reflection } \\
\text { of Climate Knowledge in Future Thinking. Climate change } \\
\text { impacts not seen as immediate but as distant in place, } \\
\text { time, and affect. Climate was not seen as an actor, unless } \\
\text { associated with energy supply and use. }\end{array}$ & $\begin{array}{l}\text { Focus: Self and Family (Personal); Knowledge and Society } \\
\text { (Social); and Climate and Threat (Environmental) sub- } \\
\text { themes. In Temporal theme Relative estimations of time } \\
\text { were heavily weighted in the past and Shift did not see } \\
\text { triggers or tipping points as immediately relevant. }\end{array}$ \\
\hline \multicolumn{3}{|l|}{ Vulnerability } \\
\hline $\begin{array}{l}\text { Active when interpreting climate } \\
\text { change knowledge and } \\
\text { considering expected changes in } \\
\text { policies and society }\end{array}$ & $\begin{array}{l}\text { Moderate involvement in Dangerous Futures, Adaptive } \\
\text { Futures, and Unfamiliar Futures (Personal). Little } \\
\text { engagement in Unfamiliar Futures (Social) or Imagined } \\
\text { Futures, vulnerability usually seen in terms of Climate } \\
\text { Knowledge, focused on the past or present. }\end{array}$ & $\begin{array}{l}\text { Focus: Emotion (Personal); Community and Institution } \\
\text { (Social); and Impact and Nature (Environmental). In } \\
\text { Temporal theme, Relative concerned mostly high impact, } \\
\text { low probability events, Shift referenced transitions where } \\
\text { reversal would be costly or impossible. }\end{array}$ \\
\hline \multicolumn{3}{|c|}{ 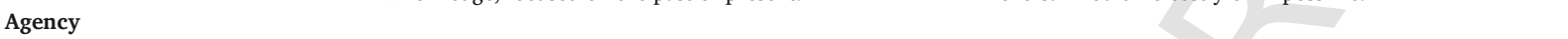 } \\
\hline $\begin{array}{l}\text { Centered on resources, abilities, } \\
\text { and opportunities to influence } \\
\text { climate change outcomes, often } \\
\text { focused on mitigation not } \\
\text { adaptation. }\end{array}$ & $\begin{array}{l}\text { High Climate Knowledge and Narrative Communication, } \\
\text { less active Future Thinking, especially in Unfamiliar } \\
\text { Futures (Personal). Personal agency sometimes expressed } \\
\text { in the negative, reinforced by occasional overestimations } \\
\text { of social agency. }\end{array}$ & $\begin{array}{l}\text { Focus: Action and Role (Personal); Resources and Values } \\
\text { (Social); and Built Environment (Environmental). In } \\
\text { Temporal theme, Relative focus was more immediate, Shift } \\
\text { included opportunities to make unavoidable changes } \\
\text { explicit to trigger new adaptation plans. }\end{array}$ \\
\hline \multicolumn{3}{|l|}{ Change } \\
\hline $\begin{array}{l}\text { Acknowledged that climate change } \\
\text { brings both present and future } \\
\text { risks that can be moderated to } \\
\text { some extent through personal } \\
\text { actions }\end{array}$ & $\begin{array}{l}\text { Reflects all FCN types. Combined Dangerous Futures and } \\
\text { Imagined Futures to develop visions of Unfamiliar Futures, } \\
\text { shared from both personal and social viewpoints. } \\
\text { Informed by all narratives, ranging from denying need for } \\
\text { autonomous adaptation, to actively adapting. }\end{array}$ & $\begin{array}{l}\text { Included all sub-themes. In Temporal theme, Relative } \\
\text { centered on the present, drawing on past experience and } \\
\text { future projections; Shift included opportunities for } \\
\text { intervention and points of no return, reflecting urgency and } \\
\text { agency to actively manage possible trajectories of change. }\end{array}$ \\
\hline
\end{tabular}

\subsection{Distance narrative: barriers to climate adaptation planning}

Participants reported rarely discussing climate change in social settings. This relative lack of engagement in Climate Change Adaptation Narratives was in itself, a powerful expression of keeping climate issues distant. Consequently, little information was shared with friends and family to support assessing what adaptation may be needed. In addition, the explicit narrative of Distance (Table 5), which was most prevalent across responses, offered little motivation or opportunity to plan and implement adaptation actions.

Key topics that emerged in narratives of Distance included: comfort; community; emergency; emotion; institution; and knowledge. For example, the interplay between comfort, community and emotion influenced when adaptation would be an acceptable topic of discussion. When talking in their community, even those who worked in climate change adaptation programs avoided adaptation as a topic, considering it demotivating for climate change conversations; as Policy-maker 6 (Can) phrased it: "Apocalypse is not an effective strategy in discussion". On personal levels, psychological distancing may also be a persistent barrier to discussing and understanding climate risks (Jones, 2012). For example, emergency and knowledge topics play an important role when considering implications of severe weather impacts such as coral bleaching due to heat extremes on the Great Barrier Reef. Researcher 5 (Australian) had no idea what the loss of corals would mean to family members who like to dive: "We've never really had discussions about ' how will you cope, what are your issues, or what do you think about?' I don't know about that."

\subsection{Vulnerability narrative: less vulnerable is not invulnerable}

In the Vulnerability narrative, climate information was usually discussed in specific, 'What if?' terms. Resulting scenarios offered distinct planning points rather than ranges of uncertainty, thus avoiding evaluating vulnerability as a moving target. Therefore, vulnerability was discussed in terms of many contrasting 'all or nothing' assessments where familiar but challenging natural hazards were of relatively little concern based on experience, while unprecedented disruptions posed unimaginable threats (Table 6).

Key topics that emerged in narratives of Vulnerability included: catastrophe; disruption; evidence; interpretation; limitations; and unknowns. For instance, the interplay between topics regarding evidence, interpretation and limitation shaped how government was seen as both offering dependable protection for society, thus reducing vulnerability; as well as increasing vulnerability by being inadequate to manage unfamiliar risks with innovative solutions. In the same way, topics about catastrophe and disruption influenced judging familiar hazards to be incrementally more threatening, based on scenarios supposing their increased scale, intensity and duration, especially when combined with other risks. Policy-maker 2 (Aus) thought simultaneous climate impacts would multiply vulnerability to devastating effect: "These things on their own might be manageable, it's the combination of them, and that's kind of pretty scary when you start thinking about all that, together". 
Table 5

Distance narrative key topics, exemplary expressions and narrative focus.

\begin{tabular}{|c|c|c|}
\hline Key topics & Exemplary expression & Distance narrative focus \\
\hline $\begin{array}{l}\text { COMFORT } \\
\text { widespread temporal } \\
\text { and spatial } \\
\text { discounting }\end{array}$ & $\begin{array}{l}\text { "Hard to imagine the society as a whole ... going to the } \\
\text { end of the century on a pathway that has that many } \\
\text { impacts from climate change." PR3A }\end{array}$ & $\begin{array}{l}\text { reluctant to imagine personal discomfort from climate change impacts - } \\
\text { used physical distance to situate climate risk elsewhere; vulnerabilities in } \\
\text { other areas not expected to affect local ecosystems and industries }\end{array}$ \\
\hline $\begin{array}{l}\text { COMMUNITY } \\
\text { future community } \\
\text { without climate } \\
\text { change }\end{array}$ & $\begin{array}{l}\text { "Big cities like Toronto have been without power for } \\
\text { four days ... dealing with it really from almost an } \\
\text { emergency preparedness perspective." PR8C }\end{array}$ & $\begin{array}{l}\text { climate threats distant from homes, even when community considered } \\
\text { vulnerable - extreme weather events discussed as natural variability to } \\
\text { engage others - energy-saving and sustainability actions labelled } \\
\text { adaptation }\end{array}$ \\
\hline $\begin{array}{l}\text { EMERGENCY } \\
\text { severe weather framed } \\
\text { as natural variability }\end{array}$ & $\begin{array}{l}\text { "The 'stationarity' of climate. ... we just can't take that } \\
\text { for granted anymore. But there are no mechanisms in } \\
\text { place to try and break open those molds. None." RE8C }\end{array}$ & $\begin{array}{l}\text { without disaster experience climate threats not considered immediate - } \\
\text { natural disasters linked to climate variability - major disruptions distant in } \\
\text { location and time - emotional detachment consciously used to reduce } \\
\text { anxiety }\end{array}$ \\
\hline $\begin{array}{l}\text { EMOTION } \\
\text { emotional distance in } \\
\text { professional } \\
\text { boundaries }\end{array}$ & $\begin{array}{l}\text { "It's very scary to internalize it... I do recognize it for } \\
\text { myself, how I stop at a certain point in my thought } \\
\text { process." PO10C }\end{array}$ & $\begin{array}{l}\text { professional boundaries required emotional distance - climate related } \\
\text { thoughts and feelings unspoken and unexamined - risks not mentioned at } \\
\text { home to distance worries for participants and families }\end{array}$ \\
\hline $\begin{array}{l}\text { INSTITUTION } \\
\text { climate outside of } \\
\text { traditional priorities }\end{array}$ & $\begin{array}{l}\text { "If you're not incorporating what the risk is in the } \\
\text { world you're responsible for, you're accountable for, } \\
\text { around climate change, what else aren't you ..." PO6C }\end{array}$ & $\begin{array}{l}\text { institutional agendas only included climate change mitigation as } \\
\text { immediate - adaptation rarely mentioned - traditional institutional } \\
\text { priorities in industry sectors and civil society did not account for climate } \\
\text { change }\end{array}$ \\
\hline $\begin{array}{l}\text { KNOWLEDGE } \\
\text { expectations based on } \\
\text { past evidence }\end{array}$ & $\begin{array}{l}\text { "It would have to be a conscious thing with data ... we } \\
\text { have to stop using this historical data because the } \\
\text { future's not going to be like that." PR1A }\end{array}$ & $\begin{array}{l}\text { multiple uncertainties make linear projections of past knowledge less } \\
\text { useful - climate impacts are not included in current decision- making - } \\
\text { unpredictability from climate change rarely considered in long-term } \\
\text { investments }\end{array}$ \\
\hline
\end{tabular}

Table 6

Vulnerability narrative key topics, exemplary expressions and narrative focus.

\begin{tabular}{|c|c|c|}
\hline Key topics & Exemplary expression & Vulnerability narrative focus \\
\hline $\begin{array}{l}\text { CATASTROPHE } \\
\text { catastrophes trigger social } \\
\text { change }\end{array}$ & $\begin{array}{l}\text { "Then you need to just continue on ... I'm } \\
\text { thinking like things ... in history that could } \\
\text { follow it through, like the Holocaust." PO8C }\end{array}$ & $\begin{array}{l}\text { catastrophe related to survival and ended topic thread - where society was } \\
\text { vulnerable, personal vulnerability was considered extreme - low } \\
\text { vulnerability expected as long as existing emergency management remains } \\
\text { useful }\end{array}$ \\
\hline $\begin{array}{l}\text { DISRUPTION } \\
\text { environmental \& social } \\
\text { change loop }\end{array}$ & $\begin{array}{l}\text { "Disruption in places like China ... I think we're } \\
\text { becoming too dependent on what ... could } \\
\text { become a highly unreliable source." PR4A }\end{array}$ & $\begin{array}{l}\text { non-climate changes and dependencies on other nations considered } \\
\text { immediate vulnerabilities and impact multipliers - immediate impacts from } \\
\text { security issues and environmental disruptions, more than from long term } \\
\text { patterns }\end{array}$ \\
\hline $\begin{array}{l}\text { EVIDENCE } \\
\text { how to reflect new } \\
\text { knowledge in policy }\end{array}$ & $\begin{array}{l}\text { "Federal government ... calling environmental } \\
\text { activists, terrorists ... there's a lot of funding } \\
\text { that's been cut back." RE9C }\end{array}$ & $\begin{array}{l}\text { governments ill-equipped to use evidence to reduce climate vulnerability - } \\
\text { science itself vulnerable from government and media - inadequate strategies } \\
\text { more influenced by politics than evidence, including consequences of } \\
\text { natural disasters }\end{array}$ \\
\hline $\begin{array}{l}\text { INTERPRETATION } \\
\text { climate change knowledge } \\
\text { needs interpretation }\end{array}$ & $\begin{array}{l}\text { "I've got reams of data to show you what that } \\
\text { means, but if you want the three-word answer it's } \\
\text { 'warmer, wetter, and wilder."' PO9C }\end{array}$ & $\begin{array}{l}\text { projections interpreted that significant impacts delayed until after their } \\
\text { lifetime - senior professionals not vulnerable due to advanced years, } \\
\text { financial security, and intellectual capabilities - interpretations not made } \\
\text { outside areas of expertise }\end{array}$ \\
\hline $\begin{array}{l}\text { LIMITATIONS } \\
\text { practices and values limit } \\
\text { new policies }\end{array}$ & $\begin{array}{l}\text { "Two levels of the government spent } 100 \text { million } \\
\text { dollars on trying to design transition strategies." } \\
\text { PO7C }\end{array}$ & $\begin{array}{l}\text { sources of vulnerability: social and financial limitations; slow uptake of } \\
\text { technologies; intractable inequities; and biophysical limits past certain } \\
\text { thresholds - some unavoidable extinction }\end{array}$ \\
\hline $\begin{array}{l}\text { UNKNOWNS } \\
\text { inexperience entering } \\
\text { unknown territory }\end{array}$ & $\begin{array}{l}\text { "A fire season as we've never seen or ... in places } \\
\text { where you don't expect it, and that's a surprise } \\
\text { that people aren't even thinking about." RE4A }\end{array}$ & $\begin{array}{l}\text { not knowing what to expect linked to frustration - specific factors such as } \\
\text { flooding could not be confidently anticipated - unfamiliar impacts and } \\
\text { management strategies limited identifying sometimes 'unimaginable' } \\
\text { vulnerabilities }\end{array}$ \\
\hline
\end{tabular}




\subsection{Agency narrative: responsibility and resources to adapt}

In the Agency narrative, a sense of agency to adapt to climate change was linked to a sense of responsibility to provide for one's own family and community, but also for the causes of anthropogenic climate change itself. Those who assessed their agency as very high compared with others also expressed awareness of having social and economic advantages compared to those within their own society and in other countries (Table 7).

Key topics that emerged in narratives of Agency included: action; advantages; infrastructure; coping; normal; and resources. For instance, topics about action, normal and coping can combine to influence a frustrated sense of agency when social support is lacking to even discuss the need for adaptation. This was articulated by Practitioner 5 (Aus), who felt dismissed by colleagues for regularly talking about climate issues: 'It's an easier thing to say, 'Well that person is just obsessed with this, and they can't let it go' ... And that's some-thing that you do have to think about'. Reflecting concerns about infrastructure and resources, Agency was commonly discussed in terms of managing floods, fires, droughts and storms by having good natural resource management, robust infrastructure and well-chosen homes. Some saw agency in the ability to avoid eventual risks by relocating, or by expecting climate threats to be delayed until after the end of their lifetime.

\subsection{Change narrative: looking toward adaptation}

In the Change narrative, those planning to adapt accepted the need to prepare in the present for future challenges, however there was no description available of a clearly shared way forward (Table 8). Key topics that emerged in narratives of Change included: acceptance; cooperate; cosmopolitan; expression; present and transform. Informed by topics of acceptance, present and transform, significant transformation was seen as highly unlikely over the twenty-year time frame of this research, so making changes too far in advance could increase vulnerability, and thus be maladaptive; or be ineffective as any benefits might be lost before they could be realized. In the face of such complex uncertainty, Policy maker 4 (Aus) discussed risk management for climate disruptions in terms of financial planning "Do you try ... to be financially comfortable in retirement? ... If we had a societal collapse, none of that would matter ... I've got to forge ahead ... because there's not much I can do in uncertain circumstances". There was little detail in personal plans to adapt to change, instead general topics were reflected, such as aiming to cooperate and be cosmopolitan, employing a few heuristics such as maintaining resilience and flexibility. The need for cooperative action was frequently mentioned, recognizing that social cohesion might be reduced and not offer the level of personal security currently experienced.

\subsection{Summary}

While participants frequently moved between narratives, the Distance narrative was dominant, where responses generally aimed to explain why adaptation was not considered an immediate concern. The Vulnerability narrative was next prevalent, where Future

Table 7

Agency narrative key topics, exemplary expressions and narrative focus.

\begin{tabular}{|c|c|c|}
\hline Key topics & Exemplary expression & Agency narrative focus \\
\hline $\begin{array}{l}\text { ACTION } \\
\text { diverse pathways } \\
\text { available for action }\end{array}$ & $\begin{array}{l}\text { "I look at the maps ... Listen to the scientists ... there } \\
\text { are going to be certain places that are going to attract } \\
\text { certain types of people." PR2A }\end{array}$ & $\begin{array}{l}\text { present action influencing by work roles - little autonomous adaptation - } \\
\text { considered joining like-minded others - used analogues of cities managing } \\
\text { drought or flood to imagine their city in the future }\end{array}$ \\
\hline $\begin{array}{l}\text { ADVANTAGES } \\
\text { past advantages offer } \\
\text { future benefit }\end{array}$ & $\begin{array}{l}\text { "It's not like we are a poor developing country. You } \\
\text { know, we are going to be okay." RE8C }\end{array}$ & $\begin{array}{l}\text { estimated high levels of social agency to manage climate impacts, } \\
\text { compared to other nations - professional agency seen as responsibility to } \\
\text { generate the best outcomes for society }\end{array}$ \\
\hline $\begin{array}{l}\text { INFRASTRUCTURE } \\
\text { physical capacity will } \\
\text { manage disruptions }\end{array}$ & $\begin{array}{l}\text { "If the entire water supply ... was cut off, or dried up } \\
\ldots \text { there's desalination plants everywhere ... but again } \\
\text { within Australian society, we are wealthy people." } \\
\text { RE3A }\end{array}$ & $\begin{array}{l}\text { robust infrastructure, and government and corporate facility management } \\
\text { reduced social risk - ability to pay higher costs for services reduced } \\
\text { personal risks - independence from water and electricity grids mentioned } \\
\text { but not enacted }\end{array}$ \\
\hline \multicolumn{3}{|l|}{ COPING } \\
\hline $\begin{array}{l}\text { Managing the } \\
\text { unavoidable }\end{array}$ & $\begin{array}{l}\text { "There's this irresistible momentum, it's just going to } \\
\text { happen. Whether you're on board are not, it's } \\
\text { happening." PO8C }\end{array}$ & $\begin{array}{l}\text { enough physical and social capital to cope in future - agency seen as } \\
\text { transferable to children - past coping proof of agency for future - little } \\
\text { detailed planning }\end{array}$ \\
\hline $\begin{array}{l}\text { NORMAL } \\
\text { normal is being } \\
\text { redefined }\end{array}$ & $\begin{array}{l}\text { "I don't think most of them would have the capacity } \\
\text { to understand how serious the changes are ... they're } \\
\text { just on normal life course." PO3A }\end{array}$ & $\begin{array}{l}\text { sustained messages of warning and urgency led to expecting a new } \\
\text { normal including climate change - family and friends not expected to plan } \\
\text { proactively, thus losing advantages of foreknowledge }\end{array}$ \\
\hline $\begin{array}{l}\text { RESOURCES } \\
\text { resource allocation will } \\
\text { change }\end{array}$ & $\begin{array}{l}\text { "I'm pessimistic ... that there would be very much } \\
\text { overt adaptation action in Canada, this society that } \\
\text { has a relatively large adaptive capacity." RE6C }\end{array}$ & $\begin{array}{l}\text { physical and economic resources more important than mental and social - } \\
\text { current agency widely expected to persist - abilities and resources } \\
\text { considered better than others in the community }\end{array}$ \\
\hline
\end{tabular}


Table 8

Change narrative key topics, exemplary expressions and narrative focus.

\begin{tabular}{|c|c|c|}
\hline Key topics & Exemplary expression & Change narrative focus \\
\hline $\begin{array}{l}\text { ACCEPTANCE } \\
\text { accepting some } \\
\text { changes and losses }\end{array}$ & $\begin{array}{l}\text { "In the farm community you can talk to anybody you } \\
\text { like about climate variability. And most of them will } \\
\text { just accept that it's going to get bigger." RE5A }\end{array}$ & $\begin{array}{l}\text { climate change real, immediate, and personally relevant - often framed as } \\
\text { natural variability to side-step contested issues of causes and projected } \\
\text { changes - frustrated by lack of political acceptance impeding adaptation }\end{array}$ \\
\hline $\begin{array}{l}\text { COOPERATE } \\
\text { co-operative } \\
\text { communities vital }\end{array}$ & $\begin{array}{l}\text { "What do we need as a family, and do we have that } \\
\text { here? And are we able to invest in the community and } \\
\text { get back from the community what we need." PR7C }\end{array}$ & $\begin{array}{l}\text { isolationist strategies rejected as reducing social and coordinated action - } \\
\text { active cooperation essential - vague notions of climate change effect on } \\
\text { children's future - collaborative skills important for adaptive advantage }\end{array}$ \\
\hline $\begin{array}{l}\text { COSMOPOLITAN } \\
\text { global ethics and } \\
\text { citizenship }\end{array}$ & $\begin{array}{l}\text { "So much about adaptation is about rebuilding } \\
\text { communities ... we have to work together and there is } \\
\text { just no other option." PR2A }\end{array}$ & $\begin{array}{l}\text { discussions more active in social settings with shared belief - climate never } \\
\text { mentioned in families entrenched in denial - ethical questions } \\
\text { communicating climate risk when information benefits some and } \\
\text { disadvantage others }\end{array}$ \\
\hline $\begin{array}{l}\text { EXPRESSION } \\
\text { allowing for a range } \\
\text { of emotions }\end{array}$ & $\begin{array}{l}\text { "We don't want to tell people that it's not viable at this } \\
\text { point because ... they're happy ... and you don't want } \\
\text { to ruin their present happiness." PO4A }\end{array}$ & $\begin{array}{l}\text { frustration and anger at slow action on climate issues freely expressed - } \\
\text { emotions such as fear rarely expressed to avoid being judged - disturbing } \\
\text { losses reframed as unlikely or unimportant }\end{array}$ \\
\hline $\begin{array}{l}\text { PRESENT } \\
\text { doing what you can } \\
\text { right now }\end{array}$ & $\begin{array}{l}\text { "And then asking yourself each time you look at that, is } \\
\text { there anything I can do now that's going to prepare } \\
\text { me? ... It's just a very slow insidious thing." PO1A }\end{array}$ & $\begin{array}{l}\text { climate impacts and social reactions discussed in the present - actions } \\
\text { included increasing self-reliance; home renovations; and community } \\
\text { presentations to influence current policies - actions usually mitigation } \\
\text { focused }\end{array}$ \\
\hline $\begin{array}{l}\text { TRANSFORM } \\
\text { transformative shifts } \\
\text { will be diverse }\end{array}$ & $\begin{array}{l}\text { "A step function ... like there's no ferries, we would be } \\
\text { eating our underwear or whatever, because we only get } \\
5 \% \text { of our food here. It's all shipped here". RE7C }\end{array}$ & $\begin{array}{l}\text { options kept flexible when uncertainty inhibited detailed planning - some } \\
\text { considered developing or joining like- minded communities with others } \\
\text { who also had knowledge or belief in climate change }\end{array}$ \\
\hline
\end{tabular}

Thinking was generally active on personal, rather than social levels, although relatively low estimations of social vulnerability sometimes reinforced a sense of distance from climate impacts. In the Agency narrative, this was reversed with Future Thinking strongly linked to social agency in terms of Climate Knowledge and personal agency in the future, rarely considered. The Change narrative was not commonly active and mainly found with participants who: saw some climate risks as likely immediate; assumed a level of both personal and social agency; and who undertook present actions to minimize their exposure to climate impacts.

The results show that these professionals who worked with climate information accepted climate change as a real and important issue and a familiar topic of work-related conversations. They were frequently involved in discussions about mitigating greenhouse gases therefore, adapting to climate change was not as commonly referenced, especially in a personal context. While projected climate change differs greatly between Australia, in the generally arid southern hemisphere and the temperate northern hemisphere climate of Canada, there were no clear corresponding differences between the participant's narratives, as climate projections were rarely reflected in much detail. Instead, participants reflected social similarities at the time, in levels of greenhouse gas emissions, economic foundations, and regulatory frameworks; and in metropolitan areas leading climate change policy development for mitigation and adaptation (Jones, 2012). An overview of the Climate Change Adaptation Narratives and their related focal types and themes is shown in Table 9.

\section{Discussion}

Four key implications can be gleaned from the findings which are important to guide future research and discussion regarding climate change adaptation. These include professional detachment from the need to adapt; focus on extreme risk assessments as opposed to personal vulnerability; imbalance between enacting personal and social agency; and avoidance of transformative adaptation.

Firstly, with respect to professional detachment to the need to adapt, the findings reinforced that climate adaptation is a novel concept, not commonly referenced or associated with risk management strategies already in use (Preston et al., 2015). Climate changed knowledge is mainly shared to support mitigation to decrease the immediacy of climate risks, especially as messages about the future climate continually reinforce that it is dangerous, so that no news is the only good news. While emotions are not often considered in adaptation planning, a study by van der Linden (2015) to consider climate risk assessments used a conceptual framework which drew on different theoretical perspectives to set out knowledge, experience, and emotional affect as key determinants for evaluating climate risk. Within this framing, affect accounted for the greatest variance in risk perceptions and interacted in complex ways with social norms (van der Linden, 2015. Such a climate risk frame gives context to consider the role of professional detachment in Climate Change Adaptation Narratives aimed at decision-makers on all levels.

Social rules limit emotional expressions in the workplace which may constrain professionals as significant actors for adaptation (Gorddard et al., 2016; Latour, 1999) and affect how climate risks are evaluated and communicated (Hurlbert \& Gupta, 2016). While this psychological distance may create a barrier to adaptation, emotive communication that reduces such distance does not 
Table 9

Climate Change Adaptation Narratives according to focal types and themes.

\begin{tabular}{|l|l|}
\hline Narrative Exemplar & Focal Types and Themes \\
\hline $\begin{array}{l}\text { Distance } \\
\text { Climate change is real, and I am concerned for future generations and } \\
\text { people in countries less able to manage it. But the big impacts will be } \\
\text { later in the century and frankly, I'Il be dead then. }\end{array}$ & $\begin{array}{l}\text { Imagined Futures - Temporal } \\
\text { Theme }\end{array}$ \\
\hline $\begin{array}{l}\text { Vulnerability } \\
\text { There are so many pressing daily issues that climate change is the least } \\
\text { of my worries. All my resources are going to high prices, kids in school } \\
\text { and my aging parents, so I'm pretty stretched. }\end{array}$ & $\begin{array}{l}\text { Dangerous Futures - Personal } \\
\text { Theme }\end{array}$ \\
\hline $\begin{array}{l}\text { Agency } \\
\text { We have social systems and infrastructure to manage big scale disasters } \\
\text { like fires and floods. If government can't manage, there is not much I can } \\
\text { do but clear the brush near the house and not live in a flood zone. }\end{array}$ & $\begin{array}{l}\text { Adaptive Futures - Personal; } \\
\text { Social Themes }\end{array}$ \\
\hline $\begin{array}{l}\text { Change } \\
\text { The last storm that came through was bigger than ever. We have been } \\
\text { talking about moving but all my family are nearby. I have a few friends I } \\
\text { can talk to who are making plans but it's hard to know what to do. }\end{array}$ & $\begin{array}{l}\text { Dutures - Personal; Social; } \\
\text { Temporal Themes }\end{array}$ \\
\hline
\end{tabular}

necessarily ensure that adaptation behavior will take place (Brügger, Morton, \& Dessai, 2016). Evaluating climate risks as immediate will not alter future visions to include climate change impacts if climate change knowledge is not reflected in mental simulations or predictions of future events, because intention-setting and planning is consequently not informed by climate information (Szpunar et al., 2014).

Secondly, perceived climate vulnerability is highly contextual, affected by expectations of being adversely affected by climate impacts. As vulnerability is not equally distributed in populations (Werg, Grothmann, \& Schmidt, 2013), it is not surprising that the educated, employed, and well-informed participants in this research counted themselves among the least vulnerable to climate impacts. Where vulnerability is assessed as low, personal disruption in the near term is not anticipated beyond relatively general inconvenience, based on past experiences and present resources. Assessments of low personal vulnerability affect adaptation planning, as expected continuation of institutional and social systems to manage natural hazards and lessen personal risk provides little motivation for autonomous adaptation (Boomsma et al., 2016; Grothmann \& Patt, 2005; Werg et al., 2013). However, assessments of personal vulnerability become extreme if unprecedented extreme weather events overwhelm systems and infrastructure, which are projected over the next twenty years to be of low probability but high impact, if they happen (Kirtman et al., 2013). If climate impacts are slow and incremental, low vulnerability means that autonomous adaptation is not needed so personal adaptation to climate change is rarely considered seriously. In contrast, if social systems and infrastructure are overwhelmed, autonomous adaptation is seen as inadequate and vulnerability equated with 'catastrophe', 'holocaust', and 'death'.

Impressions that present governance systems are not well suited to cope with the complexities of climate change are supported by other research (Coulter, 2015; Hurlbert \& Gupta, 2016; Moser \& Ekstrom, 2010), and challenge expectations that climate risks will be adequately managed by social systems in developed countries. In addition, policy research shows that, while developed countries are more likely to implement their adaptation plans compared to developing countries, they were equally unlikely to have effective adaptation outcomes to reduce vulnerabilities, in both cases largely due to insufficient information, cooperation, and guidance (Runhaar et al., 2017). As adaptation aims to reduce climate vulnerability, this research confirms other work showing the importance of individual differences in personal assessments of vulnerability to motivate adaptation (Boomsma et al., 2016; Serrao-Neumann et al., 2013).

Thirdly, familiar sources of agency inform the first strategies considered to manage climate risk by leveraging civic assets through infrastructure and government programs, and by drawing on personal financial and social resources. Where climate risks are predominantly seen in terms of natural hazards, robust social structures and advanced technologies are expected to enable sufficient preparation, response, and recovery for all but the most vulnerable (Werg et al., 2013). From both personal and policy perspectives, autonomous adaptation is not a preferred form of agency, as it is equated with unplanned reactions to climate impacts, often considered as likely inefficient, and ineffective (Preston et al., 2015). Especially in the near term, estimating low personal and high social agency offers little support to consider and discuss how agency to adapt can be supported and improved to manage climate impacts (Latour, 2014). However, autonomous adaptation is valued in some adaptation planning frameworks (Lim et al., 2005) and has been a central theme in the Danish national adaptation strategy since 2008 (Klein \& Juhola, 2014).

In addition, narratives of empowerment and action are starting to develop related to climate risks (Bai et al., 2016; Brondizio et al., 2016), where professional and personal information exchange is often focused on individual champions in communities who 
support adaptation (Berrang-Ford \& Ford, 2011). This is important, simply discussing climate change can be socially limited, depending on the dominant narratives. Lack of communication can also decrease agency to develop transformational adaptation where, by not including climate change knowledge in planning assumptions, climate information is not reflected in shared imaginings of the future (Adger et al., 2005; Tonn \& MacGregor, 2009). Instead, adaptation may be less effective through assessing decisions while assuming a stationary climate, within existing problem definitions that do not value interactions between social and personal agency (Latour, 1999). This can lead to maladaptive responses with an overreliance on social agency and little support for personal agency (Wolf, 2011).

Lastly, the Change narrative combines aspects of Future Thinking, Climate Knowledge and Narrative Communication. Deciding to adapt to climate change requires both acceptance that not all climate risks will be avoided, therefore recognizing vulnerability; and assurance that efforts can minimize future impacts, thus recognizing agency. Temporal considerations are central to adaptation where climate change is discussed as a present issue to be managed, and future climate projections are framed in familiar contexts based on past experiences (Preston et al., 2015). In this way, Future Thinking is especially active when transformative actions are considered as part of future simulations and predictions and therefore, intention setting and planning (Szpunar et al., 2014) that acknowledges likely social and environmental changes (Moser, 2016).

Rather than being proactive and transformational, adaptation is most often represented as incremental and generally expected to be reactive, not triggered until it is obviously needed (Chung Tiam Fook, 2015). This reinforces empirical evidence where, especially in developed countries, narratives of distance; low estimations of vulnerability; and overestimations of social agency pose persistent barriers to the social process of adaptation (Serrao-Neumann et al., 2015; Wolf, 2011). While most adaptation discussions are inclusive, reflecting cosmopolitan values that might lead to developing new communities with shared visions of climate risks (Gorddard et al., 2016; Harjanne, 2017), the need to be protected from other people remains a core security concern. Except for those actively planning to adapt, thoughts about adaptation are mainly kept private and for some, never shared. In this way, we can see that transformational adaptation is challenging to imagine, let alone discuss. Very intense and sudden climate change impacts are difficult to visualize and represent, so opportunities are missed to plan past tipping points to both protect what is known, and increase flexibility to support the new (Bai et al., 2016).

When considering the application of these narratives, the approach will differ depending on which is dominant in a specific interaction. It is important to remember that Distance narratives are often well grounded in fact and deserve respect. Strategies that increase knowledge adoption for adaptation will do well to plan and deliver regular updates of future-oriented temporal and spatial climate statements to keep judgements of distance up to date. Vulnerability narratives are reflective of fears and concerns for immediate or extreme risks. Adaptation risk plans need to contextualize the uncertain and ongoing nature of climate change vulnerability and encourage flexible planning practices such as adaptive management. Agency narratives assume some level of social support while taking personal responsibility as a householder. Strategies to encourage agency can use imaginative adaptation scenarios of plausible risks, modelled on medical and emergency management practices. Change narratives actively engage with adaptation and consider how to prepare for disruptions and their aftermath. Support early adapters engaged in change by addressing institutional and policy barriers to new practices and develop positive frames for autonomous adaptation.

While empirical evidence and climate change knowledge are key to professional discussions of adaptation, personal discussions refer more often to emotions and values (Spence et al., 2012), where signs of grief or distress can be acknowledged, shared, and discussed (Reser \& Swim, 2011). Bringing together professional, and personal perspectives in climate risk discussions can increase a sense of immediacy to begin adapting now.

\section{Conclusion}

This paper investigated how policy-makers, practitioners and researchers working with climate information reflected that knowledge in expectations of the next twenty years; and in what ways they shared their vision in social and personal settings to support adapting to climate change. Four resulting Climate Change Adaptation Narratives were identified: Distance; Vulnerability; Agency; and Change, with implications for future research, communication, and actions. These Climate Change Adaptation Narratives are strongly influenced by situating climate risks as distant in space, time and impacts so that there is little need to adapt to climate change. The continual focus on mitigation in climate discussion reinforces the notion that climate change is a catastrophe beyond anything that can be actively managed. While this may be true in the long run, in the near term there are opportunities for communities and individuals to reduce their vulnerability and activate their agency to prepare for likely climate impacts. Many of the barriers to adaptation do not come from climate impacts themselves, instead they are social constraints against sharing knowledge and ideas to even discuss what problems climate change presents and what solutions might be acceptable.

With its focus on the present, maintaining a mental distance from climate change risks is an effective and possibly prudent strategy to reduce anxiety. If large scale impacts do not happen within the next few decades, there is little need to devote mental energy and physical resources to autonomous adaptation. In developed nations where vulnerability to climate risk is socially low, unless overwhelming impacts make them personally high, autonomous adaptation may be both unnecessary and ineffective. Instead, it makes more sense to depend on whole-of-society climate responses, especially considering hopes for ongoing global mitigation efforts. However, when climate risk is seen as more immediate, those who have already begun adaptation planning and information sharing act on their sense of urgency, and some expect that at least one of the low probability but high impact event may begin at any time. Even those considering transformative actions to live in a new Anthropocene are limited in how and where such conversa- 
tions can be shared, as engaging in a change narrative removes the sense of distance from climate change risks that is the most common adaptation to date.

This paper provided insight into how perceptions of climate risk related to personal distance, vulnerability, and agency might influence planning for adaptation among those with ready access to climate information in developed nations. The paper showed that while all participants actively sought to mitigate climate change, few considered adaptation plans or actions for themselves or their families. Given that climate professionals in donor countries influence adaptation research, policy, and practice internationally, Climate Change Adaptation Narratives must reflect the dynamics of a climate system which is now non-stationary. This can be assisted by considering how distance, vulnerability, and agency narratives of decision-makers are shaped through research communication and reinforced within the discourse of global negotiations.

Finally, to develop well informed and well-shared Climate Change Adaptation Narratives, old understandings need to be updated with increased focus on the process of Future Thinking to continually imagine and re-imagine adaptive behaviors. Additionally, it is imperative to look beyond the scientific sphere dominating climate change adaptation discussions and planning to use learning from less-mainstream knowledge systems such as Indigenous perspectives to craft more holistic responses to climate change. It is equally important to find more ways to draw on practices of art and spirituality to develop deeper social and emotional engagement and richer narratives to promote the cultural shifts needed for ongoing and positive climate change adaptation.

\section{Acknowledgements}

This research was supported by Griffith University, with assistance from Simon Fraser University, CSIRO, and the Pacific Institute for Climate Solutions.

\section{Appendix A. Supplementary data}

Supplementary material related to this article can be found, in the online version, at doi:https://doi.org/10.1016/j.futures.2019. 05.004

\section{References}

Kirtman, B., et al., 2013. Near-term climate change: Projections and predictability. Climate change 2013: The physical science basis. Cambridge University Press, Cambridge and New York, 953-1028.

Field, C., et al., 2014. IPCC WGII AR5 technical summary, in climate change 2014: Impacts, adaptation, and vulnerability. IPCC, p. 51.

Hewitt, C.D., Stone, R.C., Tait, A.B., 2017. Improving the use of climate information in decision-making. Nature Climate Change 7 (9), $614-616$.

Bai, X., et al., 2016. Plausible and desirable futures in the Anthropocene: A new research agenda. Global Environmental Change Part A 39, 351-362.

Hurlbert, M., Gupta, J., 2016. Adaptive governance, uncertainty, and risk: policy framing and responses to climate change, drought, and flood. Risk Analysis : an Official Publication of the Society for Risk Analysis 36 (2), 339-356.

Coughlan de Perez, E., et al., 2015. Forecast-based financing: An approach for catalyzing humanitarian action based on extreme weather and climate forecasts. Natural Hazards and Earth System Science 15 (4), 895-904.

Preston, B., Mustelin, J., Maloney, M., 2015. Climate adaptation heuristics and the science/policy divide. Mitigation and Adaptation Strategies for Global Change 20 (3), 467-497.

Moser, S., 2014. Communicating adaptation to climate change: The art and science of public engagement when climate change comes home. Wiley Interdisciplinary Reviews Climate Change 5 (3), 337-358.

McNamara, K.E., Buggy, L., 2016. Community-based climate change adaptation: A review of academic literature. Local Environment 22 (4), 443-460.

Grothmann, T., Patt, A., 2005. Adaptive capacity and human cognition: The process of individual adaptation to climate change. Global Environmental Change Part A 15 (3), 199-213.

Hinkel, J., Bisaro, A., 2015. A review and classification of analytical methods for climate change adaptation. WIREs Clim Change 6 (2), $171-188$.

Klein, R.J.T., Juhola, S., 2014. A framework for Nordic actor-oriented climate adaptation research. Environmental Science \& Policy 40, $101-115$.

Petrasek MacDonald, J., et al., 2013. A necessary voice: Climate change and lived experiences of youth in Rigolet, Nunatsiavut, Canada. Global Environmental Change Part A 23 (1), 360-371.

Fløttum, K., Gjerstad, , 2017. Narratives in climate change discourse. Wiley Interdisciplinary Reviews Climate Change 8 (1), 1-15.

Milly, P.C.D., et al., 2008. Stationarity is dead: Whither water management?. Science 319 (5863), 573-574.

Craig, R.K., 2010. "Stationarity is dead"- long live transformation: Five principles for climate change adaptation law. The Harvard Environmental Law Review : HELR 34 (1), 9-73.

Smith, T.F., et al., 2011. A method for building community resilience to climate change in emerging coastal cities. Futures 43 (7), $673-679$.

Blaxekjær, , Nielsen, T.D., 2014. Mapping the narrative positions of new political groups under the UNFCCC. Climate Policy 15 (6), $751-766$.

Brondizio, E.S., et al., 2016. Re-conceptualizing the Anthropocene: A call for collaboration. Global Environmental Change Part A 39 , $318-327$.

Steffen, W., et al., 2018. Trajectories of the earth system in the anthropocene. Proceedings of the National Academy of Sciences of the United States of America 1-8.

Szpunar, P.M., Szpunar, K.K., 2016. Collective future thought: Concept, function, and implications for collective memory studies. Memory Studies 9 (4), 376-389.

Sardar, Z., 2015. Postnormal times revisited. Futures 67, 26-39.

Suddendorf, T., 2017. The emergence of episodic foresight and its consequences. Child Development Perspectives 1-5.

Szpunar, K.K., Spreng, R.N., Schacter, D.L., 2014. A taxonomy of prospection: Introducing an organizational framework for future-oriented cognition. Proceedings of the National Academy of Sciences of the United States of America 111 (52), 18414-18421.

Merck, C., Topcu, M.N., Hirst, W., 2016. Collective mental time travel: Creating a shared future through our shared past. Memory Studies 9 (3), $284-294$.

Gidley, J.M., et al., 2009. Participatory futures methods: Towards adaptability and resilience in climate-vulnerable communities. Environmental Policy and Governance 19 (6), 427-440.

Serrao-Neumann, S., et al., 2013. Climate change adaptation: Is there a role for intervention research?. Futures 53, 86-97.

Jones, C., Hine, D.W., Marks, A.D., 2017. The future is now: Reducing psychological distance to increase public engagement with climate change. Risk Analysis : an Official Publication of the Society for Risk Analysis 37 (2), 331-341.

Miller, C.A., et al., 2015. Narrative futures and the governance of energy transitions. Futures 70, 65-74.

Suddendorf, T., Corballis, M.C., 2007. The evolution of foresight: What is mental time travel, and is it unique to humans?. The Behavioral and Brain Sciences 30 (3), 299-313, discussion 313-51. 
Oakes, L.E., Ardoin, N.M., Lambin, E.F., 2016. "I know, therefore I adapt": Complexities of individual adaptation to climate-induced forest dieback in Alaska. Ecology and Society 21 (2), 1-26.

Spence, A., Poortinga, W., Pidgeon, N., 2012. The psychological distance of climate change. Risk Analysis : an Official Publication of the Society for Risk Analysis 32 (6), 957-972.

Moser, S., 2016. Reflections on climate change communication research and practice in the second decade of the 21 st century: What more is there to say?. Wiley Interdisciplinary Reviews Climate Change 345-369.

Harjanne, A., 2017. Servitizing climate science-Institutional analysis of climate services discourse and its implications. Global Environmental Change Part A 46, 1-16.

Tonn, B., MacGregor, D., 2009. Individual approaches to futures thinking and decision making. Futures 41 (3), 117-125.

Jones, S., 2012. A tale of two cities: climate change policies in Vancouver and Melbourne - barometers of cooperative federalism?. International Journal of Urban and Regional Research 36 (6), 1242-1267.

Huberman, A.M., Miles, M.B., 2002. The qualitative researcher's companion. Sage Publications, Thousand Oaks, CA.

Fereday, J., Muir-Cochrane, E., 2006. Demonstrating rigor using thematic analysis: A hybrid approach of inductive and deductive coding and theme development. International Journal of Qualitative Methods 5 (1), 80-92.

Braun, V., Clarke, V., 2006. Using thematic analysis in psychology. Qualitative Research in Psychology 3 (2), 77-101.

QSR International, 2012. NVivo qualitative data analysis software.

IPCC, 2014. Climate change 2014: Impacts, adaptation, and vulnerability. In: Field, C.B., et al. (Eds.), Working group II summary for policymakers. Cambridge University Press, Cambridge and New York.

Yusoff, K., Gabrys, J., 2011. Climate change and the imagination. WIREs Climate Change 2 (4), 516-534.

Adger, W.N., Arnell, N.W., Tompkins, E.L., 2005. Successful adaptation to climate change across scales. Global Environmental Change Part A 15 (2), 77-86.

Hornsey, M.J., et al., 2015. Evidence for motivated control: Understanding the paradoxical link between threat and efficacy beliefs about climate change. Journal of Environmental Psychology 42, 57-65.

Boomsma, C., Pahl, S., Andrade, J., 2016. Imagining change: An integrative approach toward explaining the motivational role of mental imagery in pro-environmental behavior. Frontiers in Psychology 7, 1-14.

van der Linden, S., 2015. The social-psychological determinants of climate change risk perceptions: Towards a comprehensive model. Journal of Environmental Psychology 41, 112-124.

Gorddard, R., et al., 2016. Values, rules and knowledge: Adaptation as change in the decision context. Environmental Science \& Policy 57, 60-69.

Latour, B., 1999. On recalling ANT. The Sociological Review 47 (S1), 15-25.

Brügger, A., Morton, T.A., Dessai, S., 2016. "Proximising" climate change reconsidered: A construal level theory perspective. Journal of Environmental Psychology 46, $125-142$.

Werg, J., Grothmann, T., Schmidt, P., 2013. Assessing social capacity and vulnerability of private households to natural hazards - integrating psychological and governance factors. Natural Hazards and Earth System Sciences 13 (6), 1613-1628.

Coulter, L., 2015. In: Breakey, H., Popovski, V., Maguire, R. (Eds.), Reflecting climate change impacts in governance and integrity system design, in ethical values and the integrity of the climate change regime. Routlege, Farnham, UK, pp. 105-118.

Moser, S., Ekstrom, J.A., 2010. A framework to diagnose barriers to climate change adaptation. Proceedings of the National Academy of Sciences of the United States of America 107 (51), 22026-22031.

Runhaar, H., et al., 2017. Mainstreaming climate adaptation: Taking stock about "what works" from empirical research worldwide. Regional Environmental Change $1-10$.

Latour, B., 2014. Agency at the time of the anthropocene. New Literary History 45 (1), 1-18.

Lim, B., et al., 2005. Adaptation policy frameworks for climate change: Developing strategies, policies and measures. Cambridge University Press, 258.

Berrang-Ford, L., Ford, J.D., 2011. Climate change adaptation in developed nations: From theory to practice 42, Springer, Dordrecht [Netherlands].

Wolf, J., 2011. In: Berrang-Ford, L., Ford, J.D. (Eds.), Climate change adaptation as a social process, in climate change adaptation in developed nations : From theory to practice. Springer, pp. 21-32.

Chung Tiam Fook, T., 2015. Transformational processes for community-focused adaptation and social change: A synthesis. Climate and Development 9 (1), 5-21.

Serrao-Neumann, S., et al., 2015. One human settlement: A transdisciplinary approach to climate change adaptation research. Futures 65, 97-109.

Reser, J., Swim, J.K., 2011. Adapting to and coping with the threat and impacts of climate change. The American Psychologist 66 (4), 277-289. 